\title{
Alternative technique for reducing compound waste during intravitreal injections
}

\author{
Técnica alternativa para reduzir a perda de medicação \\ durante injeção intravítrea
}

\author{
Jefferson Augusto Santana Ribeiro ${ }^{1}$ \\ André Messias ${ }^{2}$ \\ Ingrid U.Scott ${ }^{3}$ \\ Rodrig'oJorg' $\mathbf{e}^{4}$
}

Institution: Ribeirão Preto School of Medicine University of São Paulo - Ribeirão Preto (SP) - Brazil.

${ }^{1}$ Assistant physician, Department of Ophthalmology, Ribeirão Preto School of Medicine - University of São Paulo - USP - Ribeirão Preto (SP) - Brazil

${ }^{2}$ Professor of Ophthalmology, Department of Ophthalmology of USP - Ribeirão Preto (SP) - Brazil.

${ }^{3}$ Assistant Professor, Departments of Ophthalmology and Public Health Sciences, Penn State College of Medicine - Hershey (PA) - USA.

${ }^{4}$ Assistant Professor, Department of Ophthalmology of USP - Ribeirão Preto (SP) - Brazil.

Address for correspondence: Rodrigo Jorge. Faculdade de Medicina de Ribeirão Preto, Universidade de São Paulo. Av. Bandeirantes, 3.900 - $12^{\circ}$ andar do Hospital das Clínicas - Campus USP - Ribeirão Preto (SP) CEP 14049-900

E-mail: rjorge@fmrp.usp.br

Recebido para publicação em 27.05.2009

Aprovação em 20.07.2009

\begin{tabular}{|c|}
\hline ABSTRACT \\
\hline $\begin{array}{l}\text { Purpose: To describe an intravitreal injection technique using a commer- } \\
\text { cially available } 29 \text {-gauge insulin needle syringe ( } 29 \mathrm{GN} \text { syringe) and a } \\
21 \text {-gauge }(\mathrm{G}) \text { needle, comparing compound waste associated with this } \\
\text { technique application and the one described in ranibizumab (Lucentis }{ }^{\circledR} \text { ) } \\
\text { kitinstructions. Methods: Ten } 0.3 \text { ml doses of distilled water were aspirated } \\
\text { using the } 29 \mathrm{GN} \text { syringe and } 21 \mathrm{G} \text { needle (PT technique), and another ten } \\
\text { equal doses were aspirated employing the sterilized Lucentis }{ }^{\circledR} \text { kit (LK } \\
\text { technique), which contains a } 1 \mathrm{ml} \text { tuberculin syringe, a } 18 \mathrm{G} \text { needle for } \\
\text { compound aspiration and a } 30 \mathrm{G} \text { needle for intravitreal injection. For aspi- } \\
\text { ration using the PT technique, a } 21 \mathrm{G} \text { needle is attached over a } 29 \mathrm{GN} \\
\text { syringe. After compound aspiration, the } 21 \mathrm{G} \text { needle is removed and } \\
\text { intravitreal injection is performed using the } 29 \mathrm{G} \text { needle. Using a precision } \\
\text { balance, the aspiration needles }(21 \mathrm{G} \text { for PT; } 18 \mathrm{G} \text { for LK) were weighed } \\
\text { before and after water aspiration and the syringe-needle complexes for } \\
\text { injection }(29 \mathrm{GN} \text { for PT; } 30 \mathrm{G} \text { for LK) were weighed before aspiration and } \\
\text { after emptying them. The volumes left in the aspiration needles and needle- } \\
\text { syringe complexes were estimated by the difference in weight in grams, } \\
\text { which were converted to millilitres. Results: The mean ( } \pm \text { SD) residual } \\
\text { volume (ml) of aspiration needles }(21 \mathrm{G} \text { for PT; } 18 \mathrm{G} \text { for LK) was significantly } \\
\text { lower with PT technique }(0.0034 \pm 0.0016) \text { when compared to LK tech } \\
\text { nique ( } 0.0579 \pm 0.0011) \text { (p<0.01). The mean }( \pm \text { SD) residual volume (ml) of } \\
\text { syringe-needle complexes was significantly lower with PT technique } \\
\text { (0.0056 } \pm 0.0011) \text { than with LK }(0.0906 \pm 0.003 \text { ml) (p<0.01). Conclusion: } \\
\text { The proposed technique is a reasonable alternative for minimizing medi- } \\
\text { cation loss during intravitreal injection procedures. }\end{array}$ \\
\hline
\end{tabular}

Keywords: Angiogenesis inhibitors; Injections; Retinal diseases; Ophthalmologic surgical procedures; Macular degeneration; Drug administration routes; Vitreous body

\section{INTRODUCTION}

Drug administration via intravitreal injections is a frequently employed procedure ${ }^{(1-2)}$ in the management of numerous vitreoretinal diseases ${ }^{(3)}$. Intravitreal injections of anti-vascular endothelial growth factor (VEGF) drugs such as pegaptanib, bevacizumab and ranibizumab are used for the treatment of many posterior segment disorders ${ }^{(4-8)}$.

The management of wet age-related macular degeneration using ranibizumab (Lucentis ${ }^{\circledR}$ ) (Novartis ${ }^{\circledR}$, Stein, Switzerland) typically involves many intravitreal injections per patient and, consequently, high drug costs. Outside of the United States of America, ophthalmologists receive Lucentis ${ }^{\circledR}$ 
as part of a Lucentis ${ }^{\circledR} \mathrm{kit}$, which contains one vial of $0.3 \mathrm{ml} / 0.3 \mathrm{mg}$ of Lucentis ${ }^{\circledR}$, one $18 \mathrm{G}$ needle (BD ${ }^{\circledR}$ Blunt Fill Needle-Filter, $1.2 \mathrm{~mm} \times 40 \mathrm{~mm}$ ) for medication aspiration, one $30 \mathrm{G}$ needle (BD Microlance ${ }^{\circledR}$ 3, $0.3 \mathrm{~mm}$ x $13 \mathrm{~mm}$ ) for drug injection, and one $1 \mathrm{ml}$ tuberculin syringe (BD Plastipak $\left.{ }^{\circledR}\right)^{(9)}$.

According to the information sheet of Lucentis ${ }^{\circledR}$, the loss of medication after the procedure is $0.25 \mathrm{ml}$, considering the bottle dose of $0.3 \mathrm{ml}$ and the injection dose of $0.05 \mathrm{ml}$. Due to high cost and reduced medication volume per bottle, it is reasonable to use an injection technique with minimum drug loss. Thus, the objective of the present study is to report an intravitreal injection technique that reduces waste of medication and that may be extrapolated for other drugs or compounds.

\section{METHODS}

Ten $0.3 \mathrm{ml}$ doses of distilled water were aspirated employing each of 2 different techniques: the one proposed in this study and the one described in Lucentis ${ }^{\circledast}$ printed directions.

\section{Technique description}

In the proposed technique (PT), a 21 gauge (G) needle (BD PrecisionGlide ${ }^{\circledR} 21 \mathrm{G} ; 0.80 \mathrm{~mm}$ x $25 \mathrm{~mm}$ ) was attached over a 29G needle-syringe (BD Ultra-Fine ${ }^{\circledR}$ 29G, Becton Dickinson \& Co., Franklin Lakes, NJ) for compound aspiration (Figure 1). After aspiration of $0.3 \mathrm{ml}$ of distilled water from a $5 \mathrm{ml}$-beaker, the $21 \mathrm{G}$ aspiration needle was removed. Subsequently, the water was displaced from the $29 \mathrm{G}$ needle-syringe (29GN syringe) with a gentle push of the syringe plunger to the end of the syringe.

Using the Lucentis ${ }^{\circledR}$ technique (LK), an 18G needle was coupled to a tuberculin syringe and $0.3 \mathrm{ml}$ of distilled water was aspirated from a $15 \mathrm{ml}$-beaker. After aspiration, the $18 \mathrm{G}$ needle was removed, a $30 \mathrm{G}$ needle was attached to the tuberculin syringe, and water was displaced from the syringe-needle complex with a gentle push of the syringe plunger to the end of the syringe.

\section{Determination of aspiration needles compound loss}

Before and after distilled water aspiration, the aspiration needles ( $21 \mathrm{G}$ for the PT; $18 \mathrm{G}$ for the LK), without the syringes, were weighed (net weight) using a precision balance (Sartorius ${ }^{\circledR}$ BP 211D, Goettingen, Germany). The difference in weight before and after aspiration was obtained in grams and directly converted into milliliters.

\section{Determination of needle-syringe compound loss}

The 29G needle-syringe (BD Ultra-Fine ${ }^{\circledR}$, Becton Dickinson \& Co., Franklin Lakes, NJ) was weighed before distilled water aspiration and again after the distilled water was expressed from the needle-syringe. The same procedure was performed for the $30 \mathrm{G}$ needle-tuberculin syringe complex. The difference in weight before aspiration and after emptying was obtained in grams and directly converted into milliliters.

\section{RESULTS}

\section{Aspiration needles compound loss}

The mean $( \pm \mathrm{SD})$ residual volume inside aspiration needles ( $21 \mathrm{G}$ for PT; $18 \mathrm{G}$ for $\mathrm{LK}$ ) was $0.0034 \pm 0.0016 \mathrm{ml}$ and $0.0579 \pm$ $0.0011 \mathrm{ml}$, respectively, which corresponds to an average difference of $0.0545 \mathrm{ml}(\mathrm{p}<0.01)$. Thus, using the proposed technique one can save approximately $0.05 \mathrm{ml}$ of the compound per injection due to aspiration needles residual mass.

\section{Syringe-needle compound loss}

The mean \pm SD residual volume inside the combination syringe/needle was $0.0056 \pm 0.0011 \mathrm{ml}$ using BD Ultra-fine ${ }^{\circledR}$ $29 \mathrm{G}$, and $0.0906 \pm 0.003 \mathrm{ml}$ using the Lucentis ${ }^{\circledR}$ kit, which corresponds to an average difference of $0.0895 \mathrm{ml}(\mathrm{p}<0.01)$.

\section{Total compound loss}

Thus, using the proposed technique one can save approximately $0.09 \mathrm{ml}$ of the compound per injection due to the residual mass in the syringe-needle complex which may represent a total saving of $0.14 \mathrm{ml}$ per injection, when also considering the volume saving associated with a change in the aspiration needles.

\section{DISCUSSION}

The cost of anti-VEGF drugs may be substantial in the long-term management of patients with age-related macular degeneration. Therefore, an injection technique involving minimal drug waste is important. Syringes with removable needles have a "dead space" in their tip, i.e., space inside the needle where residual compound might accumulate. For example, it has been shown that insulin syringes may retain $0.05 \mathrm{ml}$ of insulin after injection ${ }^{(10)}$.

The mean residual volume left in the needle-syringe complex with the proposed technique (PT) was approximately $0.09 \mathrm{ml}$ less than that left in the needle-syringe complex when using the materials provided in the Lucentis ${ }^{\circledR}$ kit (LK). Further, the residual volume in the aspiration needles was $0.05 \mathrm{ml}$ less with PT than with LK.

Thus, the proposed technique requires a smaller drug volume to be aspirated before the injection of a determined dose due to its reduced medication loss. Also, the use of a $21 \mathrm{G}$ needle over the $29 \mathrm{G}$ needle-syringe avoids direct contact of the injection needle with drug bottle, preventing damage to the injection needle tip.

\section{CONCLUSION}

The technique presented can be implemented easily and may be a reasonable alternative for minimizing medication waste during intravitreal injection of drugs.

The authors would like to thank Professor Fernando de Queiros Cunha and his technician, Sergio Roberto Rosa, for their assistance performing the measurements described in this report. 


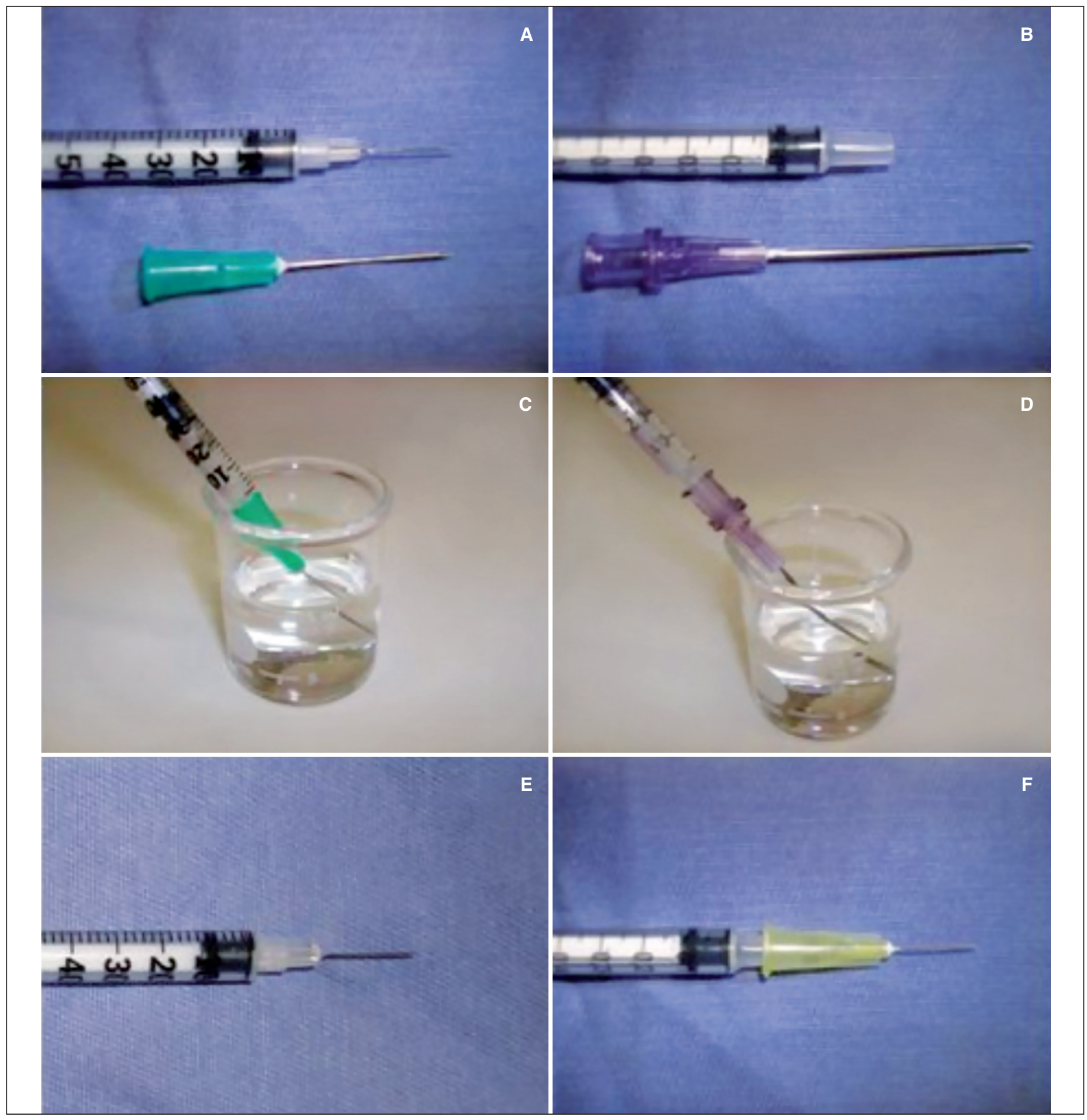

Figure 1 - Proposed technique (A, C, E) and Lucentis ${ }^{\circledR}$ kit (B, D, F) syringes and needles are shown. Aspiration needles (21G in a and $30 \mathrm{G}$ in B) are depicted with corresponding syringe (29G needle-syringe in a and tuberculin syringe in $b$ ). Aspiration of $0.3 \mathrm{ml}$ distilled water from a $15 \mathrm{ml} B$ Becker is shown (C, D). Injection needle-syringe complexes are disclosed in e (29G needle-syringe) and f (30G needle coupled to a tuberculin syringe). Note the absence of "dead space" in the $29 \mathrm{G}$ needle-syringe (E).

\section{RESUMO}

Objetivo: Descrever técnica de injeção intravítrea utilizando agulha-seringa de 29 gauge (seringa $29 \mathrm{GN}$ ) e agulha 21 gauge
(G) comercialmente disponíveis, comparando perda de composto associada à aplicação desta técnica com a descrita nas instruções do kit do ranibizumabe (Lucentis ${ }^{\circledR}$ ). Métodos: Dez doses de $0,3 \mathrm{ml}$ de água destilada foram aspiradas com a seringa 
29GN e a agulha 21G (técnica PT) e outras dez doses iguais foram aspiradas utilizando-se o kit do Lucentis ${ }^{\circledR}$ (técnica LK). Para aspiração com a técnica PT, a agulha $21 \mathrm{G}$ é colocada sobre a seringa $29 \mathrm{GN}$. Depois da aspiração, a agulha $21 \mathrm{G}$ é removida e a injeção intravítrea é realizada com a agulha $29 \mathrm{G}$. A técnica LK utiliza seringa de tuberculina de $1 \mathrm{ml}$ acoplada a agulha $18 \mathrm{G}$ para aspiração e agulha $30 \mathrm{G}$ para injeção intravítrea. Usando balança de precisão, as agulhas de aspiração (21G para PT; $18 \mathrm{G}$ para LK) foram pesadas antes e depois da aspiração da água e os complexos agulha-seringa para injeção (29GN para PT; 30G para LK) foram pesados antes da aspiração e após serem esvaziados. Os volumes restantes nas agulhas de aspiração e complexos agulha-seringa foram estimados pela diferença dos pesos em gramas com conversão para mililitros. Resultados: $O$ volume $(\mathrm{ml})$ residual médio $( \pm \mathrm{DP})$ das agulhas de aspiração (21G para PT; $18 \mathrm{G}$ para LK) foi significativamente menor com a técnica PT $(0,0034 \pm 0,0016)$ quando comparado à técnica $\operatorname{LK}(0,0579 \pm 0,0011)(\mathrm{p}<0,01)$. $\mathrm{O}$ volume $(\mathrm{ml})$ residual médio $( \pm \mathrm{DP})$ dos complexos agulha-seringa foi significativamente menor com a técnica PT $(0,0056 \pm 0,0011)$ do que LK $(0,0906 \pm 0,003 \mathrm{ml})(\mathrm{p}<0,01)$. Conclusão: A técnica de injeção proposta é uma alternativa razoável para minimizar perda de medicação durante aplicação de injeções intravítreas.

Descritores: Inibidores da angiogênese; Injeções; Doenças retinianas; Procedimentos cirúrgicos oftalmológicos; Degeneração macular; Vias de administração de medicamentos; Corpo vítreo

\section{REFERENCES}

1. Aiello LP, Brucker AJ, Chang S, Cunningham ET Jr, D’Amico DJ, Flynn HW $\mathrm{Jr}$, et al. Evolving guidelines for intravitreous injections. Retina. 2004;24(5): S3-19. Comment in: Retina. 2005;25(7):949-50; author reply 950.

2. Bonini-Filho MA, Jorge R, Barbosa JC, Calucci D, Cardillo JA, Costa RA. Intravitreal injection versus sub-Tenon's infusion of triamcinolone acetonide for refractory diabetic macular edema: a randomized clinical trial. Invest Ophthalmol Vis Sci. 2005;46(10):3845-9.

3. Jaissle GB, Szurman P, Bartz-Schmidt KU; German Retina Society; German Society of Ophthalmology; German Professional Association of Ophthalmologists. [Recommendation for the implementation of intravitreal injections-statement of the German Retina Society, the German Society of Ophthalmology (DOG) and the German Professional Association of Ophthalmologists (BVA)]. Klin Monatsbl Augenheilkd. 2005;222(5):390-5. German.

4. Costa RA, Jorge R, Calucci D, Melo LA Jr, Cardillo JA, Scott IU. Intravitreal bevacizumab (Avastin) for central and hemicentral retinal vein occlusions IBeVO study. Retina. 2007;27(2):141-9.

5. Costa RA, Jorge R, Calucci D, Cardillo JA, Melo LA Jr, Scott IU. Intravitreal bevacizumab for choroidal neovascularization caused by AMD (IBeNA Study): results of a phase 1 dose-escalation study. Invest Ophthalmol Vis Sci. 2006; 47(10):4569-78.

6. Takeda AL, Colquitt J, Clegg AJ, Jones J. Pegaptanib and ranibizumab for neovascular age-related macular degeneration: a systematic review. Br J Ophthalmol. 2007;91(9):1177-82.

7. Fung AE, Rosenfeld PJ, Reichel E. The International Intravitreal Bevacizumab Safety Survey: using the internet to assess drug safety worldwide. Br J Ophthalmol. 2006;90(11):1344-9. Comment in: Br J Ophthalmol. 2006;90(11):1333-4; Br J Ophthalmol. 2006;90(11):1440.

8. Apte RS. Pegaptanib sodium for the treatment of age-related macular degeneration. Expert Opin Pharmacother. 2008;9(3):499-508.

9. Novartis. Lucentis [bula on Internet]. Switzerland: Novartis. [cited 2009 Jan 12]. Available from: http://www.medicinanet.com.br/bula/3194/lucentis.htm

10. Souza CR, Zanetti ML. Administração de. insulina: uma abordagem fundamental na educação em diabetes. Rev Esc Enferm USP 2000;34(3):264-70. 